\title{
The Press and Nigeria’s Afrocentric Foreign Policy: A Content Analysis
}

\section{Onworgu $\mathrm{K}^{*}$}

Department of Mass Communication, Faculty of Social Scencesi, Imo State University Owerri, Nigeria

\begin{abstract}
The study is a ten year study (1999-2009). It involved both content analysis and historical study. Total sample sizes of 227 editions were used from an accessible population of 1,133 drawn using Australian Calculator from five daily Nigerian newspapers, namely: Daily Times, Daily Champion, The Vanguard, The Guardian and This Day newspaper. All the newspapers are privately owned except Daily Times, which, hitherto, was owned by the Federal Government of Nigeria. These newspapers were selected because of their objectivity in writing reporting and their national spread. The instrument for data collection was the code sheet. The code sheet was constructed to contain such data as unit of analysis, depth of the stories (measured in inches), sources of information, content categories, directionality and placement of the stories. Also, we did a constructed years, months and days study. The constructed years at one interval included 2000, 2002, 2004, 2006 and 2008. For the constructed months of study, we had January, March, May, July, September and November. To determine the number of editions to be studied from each paper, for five and months, within the selected years and months, we used multi-stage sampling and divided the sample size of 227 by the number of years (5) studies and we got 45 editions per year. To further get the editions for paper, per month, the newspaper were stratified into months (constructed for the study) and we had eight (8) edition paper per month.
\end{abstract}

Keywords: The press; Foreign policy; Afro-centrism

\section{Background to the Study}

Africa and African affairs are the centerpiece of Nigeria's foreign policy since independence in 1960. To this end, Nigeria had participated in the liberation and decolonization of many African countries, including support for the dismantling of apartheid in South Africa in the 90s. However, Nigeria is criticized for not benefitting from or getting reciprocal gestures from other African countries despite her big brother roles in the continent. Over the years other African countries have tended to ignore the contributions of Nigeria in peace keeping not only in West Africa but in the whole of Africa. Also, there has been inconsistence in the determinants of Nigeria's foreign policy. This is caused by the series of military regimes which have left the nation with no fewer than eleven Heads of State in about 52 years of national independence. This excludes periods of colonial rule with a number of Governor-Generals. Although after independence, the nation's leaders tried to articulate the nation's foreign policy to mean a commitment to the course of African Liberation. With Africa as Nigeria's foreign policy thrust, the nation became deeply involved in the struggle for independence of African States. Little Wonder, she was at the centre of the formation of both regional and sub-regional bodies, including Organisation of African Unity (OAU) now African Union (AU) and Economic Community of West African States (ECOWAS), among others. With the political independence of almost all African states, the nation needs to redefine her foreign policy thrust in line with the present political and socio-economic realities.

The Nigeria's involvement in the regional peace keeping effort is a welcome development. But care should be taken to avoid to be seen as becoming a regional police or bully. The extent to which the peace keeping force (ECOMOG) has actually achieved peace in the trouble countries of Liberia and Sierra Leone is yet to be seen. It is on record that these peace keeping operations are costing the nation a lot both in men and material resources. Then the question remains, shall we continue to maintain military presence through ECOMOG as long as these ethnic wars go on ad infinitum in West Africa? Again, shall we continue to help other African countries, while the nation is at the verge of collapsing economically and politically? Couldn't the millions of dollars we spent in Liberia and Sierra Leone and other war torn countries be rechanneled towards the provision of basic infrastructure for Nigerian citizens? One tends to agree with the opinion of Dr. Kayode Familoni in The Source Magazine of August 4, 1997; that: ECOMOG having gulped billions of dollars which should have been invested sufficiently on poverty alleviation, there is now the need for the nation to strike a balance between the external obligation, particularly within the sub-region and the domestic obligations". To this effect, This Day editorial put the cost of ECOMOG operations in Liberia and Sierra Leone as of 2001, at $\$ 13$ billion.

\section{Statement of the Problem}

Does Nigeria, press reportage highlight the Afrocentric foreign policy of the nation? Do the reports analyze the benefits of such foreign policy for both Nigerian government and Nigerian citizens? What are the nature, directionality, content categories and depth of press reportage on Afrocentric Nigerian foreign policy within the period of the study? In analyzing the foreign policy of Nigeria, the questions that therefore arise are: how have the changes in the international system in last fifty years been perceived and interpreted by the policy makers? How has Nigeria's national interest been defined, in context of those changes? What specific policies have been formulated and implemented to respond to the changes? What has been the impact of the changes and Nigeria's responses on Nigeria's national development? These questions provide basis for the study not only for policy makers and implementers but for the member of the press who are expected to

*Corresponding author: Onworgu K, Department of Mass Communication, Faculty of Social Scencesi, Imo State University Owerri, Nigeria, Tel: +08062303484; Fax: +902124607070; E-mail: konworgu@yahoo.com

Received December 21, 2017; Accepted April 19, 2018; Published April 23, 2018

Citation: Onworgu K (2018) The Press and Nigeria's Afrocentric Foreign Policy: A Content Analysis. J Mass Communicat Journalism 8: 366. doi: 10.4172/21657912.1000366

Copyright: (c) 2018 Onworgu K. This is an open-access article distributed under the terms of the Creative Commons Attribution License, which permits unrestricted use, distribution, and reproduction in any medium, provided the original author and source are credited. 
provide adequate information and scrutinize some of these policies not only for Nigerians but also for the neighboring African countries. This is necessary because the press in Nigeria may not have given Nigeria's Afrocentric foreign policy the needed support and reportage.

\section{Objectives of the Study}

The study tried to achieve the following objectives:

- Identifying the story types, sources and volume of reportage on Nigeria's relationship with other African countries;

- Ascertaining the directionality and prominence of press reportage on Nigeria's relationship with other African countries;

- Identifying the content categories of press reports on Nigeria's relationship with other African countries.

\section{Research Questions}

RQ1: What are the types, sources and volume of reportage by the Nigerian press on Nigeria's relationship with other African countries?

RQ2: What are the directionality and prominence of press reportage on Nigeria's relationship with other African countries?

RQ3: What are the content categories of press reports on Nigeria's relationship with other African countries?

\section{Review of Literature}

\section{The press and Nigerian foreign policy thrust}

A new policy thrust for the nation should be one that will place national interest above any other interests. There is the call for Nigeria to adopt diplomacy of selective engagement, act quietly when necessary and promote informal diplomacy. A policy that will ensure the protection and defense of these interests whenever and wherever they are being threatened. However, in the opinion, of The Guardian "ECOMOG represents the pioneer example of peace enforcement by any regional organization. In this respect, ECOMOG rightly symbolises Africa's flagship in international peace keeping and peace enforcement, as well as the finest demonstration, of African responsibility and African capacity in resolving African problems, it could be fool - hardy to continue to support a peace keeping mission that looks unending".

The nation's new policy thrust should be to give support to only those warring factions that are ready to call for a peaceful resolution to their conflict. The country cannot continue to waste scarce resources in trying to maintain peace where the warring factions are not even ready to give peace a chance [1]. In a situation where the nation's hospitals are without drugs, our filling stations without petrol, diesel or gas, our schools without books or instructional materials and our roads have become death traps, the nation cannot but redirect our priorities, especially in the area of external spending and engage in programmes of actions, with the aim of providing the citizens with their basic needs [2]. Successive governments in the country have clearly articulated the nation's foreign policy thrust which is to liberate African countries from both economic and political slavery. Hence, Africa has been the centre-piece of Nigeria's foreign policy. Now that most countries in Africa have gained political independence, a lot still need to be done to make them attain economic freedom. Therefore, one should expect Nigeria's foreign policy to shift to economic empowerment of African nations. Since the country's foreign policy was focused on anti-apartheid regime in South Africa and with the dismantling of apartheid regime in South Africa and liberation of most African states from the white dominated regimes, where lays our new policy? One expects Nigeria's foreign policy to deviate from the typical "fire-bridge" approach to more planned, sustainable and problem - solving policies. Nation-States plan their foreign policy goals and objectives decades before they came to fruition. This can only be achieved if all the sectors of our society, including the press are involved.

\section{Press and the benefits of Nigeria's foreign policy thrust}

Ironically, African countries, including, Nigeria are battling with the process of installing democratic rules and this has affected the nation's efforts at fashioning out a positive foreign policy. In formulating foreign policy, the government should be guided by the views of Ibrahim Lincoln, who said, that everything can succeed with public sentiment. The public will always identify and rely on the press for direction on most issues, including foreign policy issues. Hence, for any policy to succeed, the support and sympathy of the press is needed [3]. The nation needs a multi-faceted and a multi-directional approach towards selling her policy, objectives and initiatives to the international community. There should be efforts geared towards marketing of the nation's socio-economic scientific and technological ideas and policies to other countries, through a well planned and executed line of action and communication [4,5]. Also integrated foreign policy strategies involving external and internal publicity of our policies and programmes through the various media of mass communication, including the press should be adopted.

\section{Theoretical Framework}

This paper is anchored on globalization concept. Most issues and researches about globalization have revolved around international relations, comparative political economy, International political economy; Political Theory, Sociology and Economic growth, academic discourse [6], Fiscal Policy, trade and taxation [7], politicaltransnationalization and activities of transnational corporations, to the exclusion of communication and information globalization. However, the disadvantages of globalization have attracted scholarship and interests from a wide range of academics. Also, it has alleged that a high level of insecurity that has accompanied globalization is seen in alarmingly rate of cross border crime [8]

African societies including Nigeria are today under siege and are struggling to maintain not only (their) various national sovereignties but also their right to existence. Today, the mechanisms of exploiting and controlling the developing countries policies are maintained with the assistance of improved technology, especially, information technologies. Those in power in the first world have hailed the coming of these technologies which make it possible for the global dissemination of their ways of life in support of their vest financial interests as one of the greatest inventions of our time.

Central to this concept is the internet - the "net" that sprawling collection of data residing on computers around the world and accessible by high-speed connections. Everything that presently exists on a personal computer, experts suggest, will move onto the internet, giving us greater mobility and wrapping, the internet around our lives.

Globalization scholars and researchers have not really agreed on a single definition to the term globalization. The issue of globalization has attracted both support and condemnations. For those who are against it, it has become another economic reductionism, a technological determinism and "political cynicism" [9]. It is seen as instrument for further marginalization of the developing countries 
by the developed nations, instead of being object of development $[10,11]$. For those in support of globalization, it is synonymous with international cooperation [12]. Globalization is most times portrayed as a way to increase diversity and the richness of culture by adding to the variety of information circulating in the media. But the reality however is to the contrary, as the global media are only dominated by Western Hollywood values, Western products, perspectives and culture. Without argument, the English Language has become the carrier of this Western hegemonic culture [13]. However, globalization has also become an irresistible force and process.

Therefore, globalization has led to such issues as cosmopolitanism; Cybercrime on a higher scale; political violence weapon proliferation and violence against refugees. The globalization of networks is facilitating criminal activities, ranging from cybercrimes which are on the increase to terrorist networks and drug syndicates. Though globalization seems like an element of energy and progress for humanity as a whole, it is nevertheless filled with various risks, financial crises, financial criminal activities, financial speculations, and terrorism [14]. Therefore, it looks like globalization is synonymous with information, commodities, money flow and crimes across national boundaries. Some authors have argued along the line of the emerging world of global interconnections and the debates surrounding it, particularly, as they affect the issues of crime, deviance and social control.

Moreover, cyberspace has become an important focus of political communication and identity formation, particularly for younger population in developing countries, as well as, for various militant Islamic groups. Today, there is the talk of the virtual office, virtual university, virtual relationship, virtual tours and even virtual warfare. It is not uncommon in academic discussion too, for a phenomenon of importance (or reality) to be illustrated by the number of hits it gets on the internet. In Nigeria, globalization has been viewed from different perspectives by different authors. For instance, Derefaka [15] sees it from "cultural identity". To Taiwo Nigerians are being greatly influenced culturally by globalization to the extent that the youths are consciously adopting western cultural values to detriment of indigenous culture. However, Fakiyesi [16] Opines that globalization can increase worldwide interdependence of most economics, advising that Nigeria should move with the current by embracing globalization. The Afrocentric foreign policy of Nigeria is aimed at opening up to other African countries through economic and social cooperation. This is the hallmark of globalization and has become the essence of Nigeria's foreign policy.

\section{Research Methodology}

The study is a ten year study (1999-2009). It involved both content analysis and historical study. A total sample size of 227 editions were used from an accessible population of 1,133 drawn using Australian Calculator from five daily Nigerian newspapers, namely: Daily Times, Daily Champion, The Vanguard, The Guardian and This Day newspaper. All the newspapers are privately owned except Daily Times, which, hitherto, was owned by the Federal Government of Nigeria. These newspapers were selected because of their objectivity in writing reporting and their national spread. The instrument for data collection was the code sheet. The code sheet was constructed to contain such data as unit of analysis, depth of the stories (measured in inches), sources of information, content categories, directionality and placement of the stories.

Also, we did a constructed years, months and days study. The constructed years at one interval included 2000, 2002, 2004, 2006 and 2008. For the constructed months of study, we had January, March, May, July, September and November. To determine the number of editions to be studied from each paper, for five and months, within the selected years and months, we used multi-stage sampling and divided the sample size of 227 by the number of years (5) studies and we got 45 editions per year. To further get the editions for paper, per month, the newspaper were stratified into months (constructed for the study) and we had eight (8) edition paper per month. There, we selected eight editions from a bundle of 30 edition of the selected newspaper, using one day interval in most cases, excluding Saturday and Sunday edition. The data were analysed and presented using simple percentage frequency tables, and bar charts. Intercoder reliability level was achieved using subsample $10 \%$ of the contents as suggested by Lacy and Riffle. Three coders were used to code the subsample of 32 units, using a reconstructed formula for:

$$
\frac{24}{N_{1}+N_{2}}
$$

where $\mathrm{M}$ is the number of coding.

Decision in which two coders agreed, N1 and N2 are the total number of coding decisions by the first and second respectively. Hence, we got $92 \%$ reliability level (Figure 1).

\section{Data Presentation and Analysis}

Breakdown of the data on sources of information on Nigeria's relationship with other African countries shows, The Guardian newspaper did not use government sources in her story. This Day had 6.7\% Daily Champion had 40\%; The Vanguard had $26.7 \%$ and Daily Times had $26.7 \%$ from government sources. On the use of corporate bodies as source(s) of story on Nigeria's relationship with other African countries The Guardian newspaper had 16.1\%, This Day newspaper

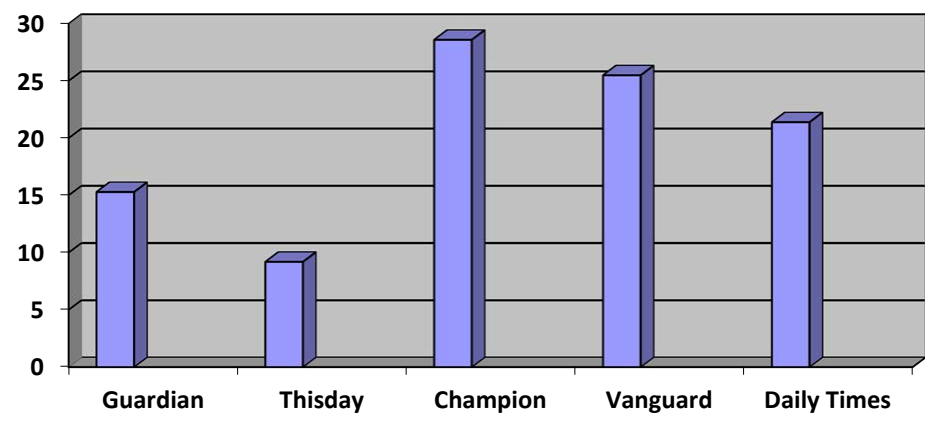

Figure 1: Represent on Nigeria's relationship with other African countries. 
Citation: Onworgu K (2018) The Press and Nigeria's Afrocentric Foreign Policy: A Content Analysis. J Mass Communicat Journalism 8: 366. doi: 10.4172/2165-7912.1000366

Page 4 of 7

had $16.1 \%$, This Day newspaper had $6.5 \%$ on individuals as sources of getting story on the issue, the Guardian had 5\%, Champion had $50 \%$ while This Day, The Vanguard and Daily Times had no report. On reporters originated stories, the Guardian had 1 item (5.99\%) This Day had $11.8 \%$, Daily Champion had $29.4 \%$. On reports coming from envoys, The Guardian had 24.2\%, This Day had $12.1 \%$ Daily Champion had $15.2 \%$ The Vanguard had $18.2 \%$ and Daily Times had $30.3 \%$. The data shows that for the issue on Nigeria's relationship with other African countries, stories from corporate bodies and envoys formed the bulk of the sources of information (Table 1 and Figure 2).

From the above Table 2 and Figure 2 above, it is clear that The Vanguard newspaper had the highest source of information with $22.6 \%$ followed by The Daily Champion with $21.7 \%$. The Daily Times had 20.4\% followed by The Guardian with $16.7 \%$ (Figure 3).

Table 3 and Figure 3 above show clearly that The Champion, The Vanguard and The Daily Times newspaper had more content categories with 26 items 25 and 21 items respectively. This Day had the least with 9 items. Meanwhile the economic relations had the highest content categories with $64.3 \%$. There was no data on reaction of Nigerians. Political relations had (5.1\%). A breakdown of the data shows that The Daily Champion and the Vanguard had 3.8\% each on Nigeria's political relations with other African countries. The Daily Times had 3.1\%. Hence, The Guardian had 59\%, The Daily Champion had 3.8\% and The Daily Times had $3.8 \%$, social relations yielded $27.69 \%$. A breakdown of data show that all the papers had reports on social relations. For instance, the Guardian had 17.6\%, This Day 44.4\%, Daily Champion 19.2\%, The Vanguard had 19.2\% and The Daily Times had 38.1\%.

On Nigeria's cultural relations with African countries, The Guardian had 5.9\%; The Daily champion had 3.8\%, The Vanguard had $3.8 \%$. This Day and Daily Times had no publication. On the Nigeria's social relations with other African countries, The Guardian had 17\%, This Day $44.4 \%$, The Daily Champion $19.2 \%$; The vanguard $19.2 \%$ and The Daily Times $38.1 \%$. On the reactions of Nigerian citizens to Nigeria's relationship with African countries, no paper had a report (Figure 4).

\begin{tabular}{|c|c|c|c|c|c|c|}
\hline Categories & Government & Corporate Bodies & Individuals & Reporters & Envoy & Total \\
\hline The Guardian & & $5(16.1 \%)$ & $1(50 \%)$ & $1(5.9 \%)$ & $8(24.2 \%)$ & $15(15.3 \%)$ \\
\hline This Day & $1(6.7 \%)$ & $2(6.5 \%)$ & & $2(11.8 \%)$ & $4(12.1 \%)$ & $9(9.2 \%)$ \\
\hline The Champion & $6(40 \%)$ & $11(35.5 \%)$ & $1(50 \%)$ & $5(29.4 \%)$ & $5(15.2 \%)$ & $28(28.6 \%)$ \\
\hline The Vanguard & $4(26.7 \%)$ & $11(35.5 \%)$ & & $4(23.5 \%)$ & $6(18.2 \%)$ & $25(25.5 \%)$ \\
\hline Daily Times & $4(26.7 \%)$ & $2(6.5 \%)$ & & $5(29.4 \%)$ & $10(30.3 \%)$ & $21(21.4 \%)$ \\
\hline Total & $15(100 \%)$ & $31(100 \%)$ & $2(100 \%)$ & $17(100 \%)$ & $33(100 \%)$ & $98(100 \%)$ \\
\hline
\end{tabular}

Table 1: Data on sources (1999-2009) Nigeria's relationship with other African countries.

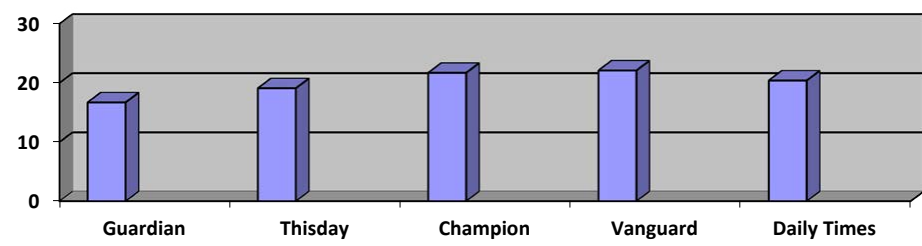

Figure 2: Representing the volume of the story (inches) on Nigeria's relationship with other African countries.

\begin{tabular}{|c|c|c|c|c|c|c|}
\hline Categories & Government & Corporate Bodies & Individuals & Reporter envoy & Envoy & Total $/ \%$ \\
\hline The Guardian & & $91(16.1 \%)$ & $12.5(100 \%)$ & $31(9.3 \%)$ & $126.5(26.5 \%)$ & $261(16.7 \%)$ \\
\hline This Day & $22(12.5 \%)$ & $143(25.3 \%)$ & & $61(18.3 \%)$ & $73(15.3 \%)$ & $299(19.1 \%)$ \\
\hline The Daily Champion & $63(35.8 \%)$ & $154.5(27.4 \%)$ & - & $62(18.6 \%)$ & $60(12.6 \%)$ & $339.5(21.7 \%)$ \\
\hline The Vanguard & $2(23.9 \%)$ & $149(26.4 \%)$ & & $91.5(27.5 \%)$ & $63(13.2 \%)$ & $345.5(22.1 \%)$ \\
\hline Daily Times & $49(27.8 \%)$ & $27(4.8 \%)$ & & $87.5(26.3 \%)$ & $155.5(32.5 \%)$ & $319(20.4 \%)$ \\
\hline Total & $176(100 \%)$ & $564.5(100 \%)$ & $12.5(100 \%)$ & $333(100 \%)$ & $478(100 \%)$ & $1564(100 \%)$ \\
\hline
\end{tabular}

Source: Newspaper Content Analysis.

Table 2: Data on volume of the story (inches) from 1999-2009 on Nigeria's relationship with other African countries.

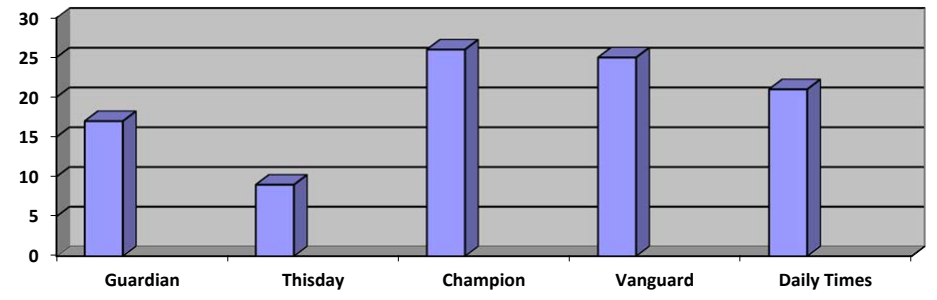

Figure 3: Graph representation on Nigeria's relationship with other African countries. 
Citation: Onworgu K (2018) The Press and Nigeria's Afrocentric Foreign Policy: A Content Analysis. J Mass Communicat Journalism 8: 366. doi: 10.4172/2165-7912.1000366

Page 5 of 7

\begin{tabular}{|c|c|c|c|c|c|c|}
\hline Content Categories & The Guardian & This day & The Champion & The Vanguard & Daily Times & Total \\
\hline Economic Relations & $13(76.5 \%)$ & $5(55.6 \%)$ & $19(73.1 \%)$ & $16(6 \%)$ & $10(47.6 \%)$ & $63(64.3 \%)$ \\
\hline Political Relations & & & $1(3.8 \%)$ & $1(3.8 \%)$ & $3(14.3 \%)$ & $5(5.1 \%)$ \\
\hline Cultural Relations & $1(5.9 \%)$ & & $1(3.8 \%)$ & $1(3.8 \%)$ & & $3(3.1 \%)$ \\
\hline Social Relations & $3(17.6 \%)$ & $4(44.4 \%)$ & $5(19.2 \%)$ & $5(19.2 \%)$ & $8(38.1)$ & $27(27.6 \%)$ \\
\hline Reactions of Nigerians & & - & - & - & - & - \\
\hline Total & 17 & $9(100 \%)$ & $26(100 \%)$ & $25(100 \%)$ & $21(100 \%)$ & $98(100 \%)$ \\
\hline
\end{tabular}

Table 3: Content categories on Nigeria's relationship with other African countries.

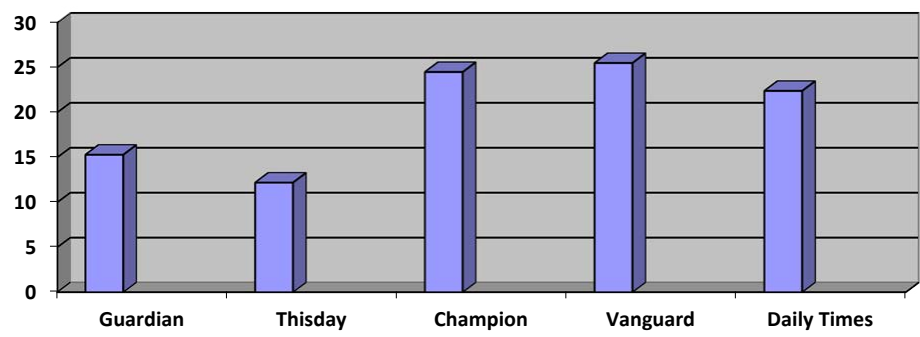

Figure 4: The unit of analysis on Nigeria's relationship with other African countries.

\begin{tabular}{|c|c|c|c|c|c|c|c|}
\hline Paper Titles & Editorials & News stories & Letter to Editor & Cartoons & Features & Photograph & Total \\
\hline The Guardian & & $14(17.9 \%)$ & $1(50 \%)$ & & $1(25 \%)$ & & $15(15.3 \%)$ \\
\hline This Day & & $8(10.3 \%)$ & & & $1(25 \%)$ & $3(25 \%)$ & $12(12.2 \%)$ \\
\hline The Champion & & $20(25.6 \%)$ & & & $1(25 \%)$ & $3(25 \%)$ & $24(24.5 \%)$ \\
\hline The Vanguard & $1(50 \%)$ & $20(25.6 \%)$ & & & $1(25 \%)$ & $3(25 \%)$ & $25(25.5 \%)$ \\
\hline Daily Times & $1(50 \%)$ & $16(20.5 \%)$ & $1(50 \%)$ & & $1(25 \%)$ & $3(25 \%)$ & $22(22.4 \%)$ \\
\hline Total & $2(100 \%)$ & $78(100 \%)$ & $2(100 \%)$ & & $4(100 \%)$ & $12(100 \%)$ & $98(100 \%)$ \\
\hline \multicolumn{7}{|c|}{ Source: Newspaper Content Analysis. } & \\
\hline
\end{tabular}

Table 4: Unit analysis on Nigeria's relationship with other African countries.

In the Table 4 and Figure 4 above, it is clearly indicated that the Vanguard Newspapers had the highest percentage on Unit of Analysis with $25.5 \%$. It is closely followed by Champion and Daily Times Newspapers with 24.5 and $22.4 \%$ respectively. Meanwhile, News stories had the highest Unit of Analysis with 78 items out of 98. A breakdown of the unit of analysis shows that The Guardian and This Day newspapers had no editorial on the issue of Nigeria's relationship with other African countries, while The Vanguard and Daily Times had 1 item each, representing 50\% each. On news stories, a break of such data showed that The Guardian had $17.9 \%$, This Day newspaper had $10.3 \%$, The Daily Champion and The Vanguard $25.6 \%$ each, The Daily Times had $20.5 \%$ on letters-to-the editor, as a unit of analysis, only The Vanguard and The Guardian had 50\% each. Features as a unit of analysis had $25 \%$. From each paper also on photograph as unit of analysis, all the papers had 25\% each (Figure 5).

From the Table 5 and Figure 5 above, it was revealed that The Daily Champion newspaper had the highest on directionality and prominence with $26.5 \%$. This is closely followed by The Vanguard newspaper with $26.5 \%$ and Daily Times with $21.4 \%$. This Day had the least with $10.2 \%$. Meanwhile, the inside pages had more information with 43 items out of 98 items. The Back Page had the least with only 2 items. A breakdown of the data shows The Guardian had 21.4\%; The Champion had 28.6\%; The Vanguard had 21.4\% and The Daily Times $21.4 \%$. Also, The Guardian had $11.1 \%$ as unfavourable story, This Day had 22.2\%, The Daily Champion had 22.2\%, The Vanguard and Daily Times had 22.2\% each. Neutral stories had The Guardian and This Day had 9.1\% each, Daily Champion and The Vanguard had 36.4\% each and Daily Times had $9.1 \%$.
On prominence, The Guardian had $20 \%$ as front page stories and Daily Times 4 (80\%). Also, The Guardian and The Vanguard had one back page story each, other papers did not have. However, all the papers had Front Page stories as follows: The Guardian 14.0\%, This Day had $11.6 \%$, Daily Champion $27.9 \%$, The Vanguard had $27.9 \%$ and Daily Times had $18.6 \%$.

\section{Discussion of Findings}

\section{Nigeria's relationship with other African countries}

Africa is the centre-piece of Nigeria's foreign policy. This foreign thrust makes it imperative that Nigeria must relate cordially and mutually with other African countries. The Afrocentric nature of Nigeria's foreign policy made it possible for the country to support the liberation efforts and struggle for independence by so many African countries, especially, those in Southern Africa. To this end, Nigeria fought for the liberation of South Africa from Apartheid regime and also supported the liberation movements in Namibia, Zimbabwe and Botswana. However, there is a snag in Nigeria's foreign policy towards African countries. The country seems not to benefit economically from her efforts in helping African brothers [3].

This big brother posture is not backed up by economic, social and even political benefits for Nigerians. All the same, within the period under review (1999-2009), efforts were made by Nigerian government towards economic and citizens' diplomacy. To this end, Nigerian press should now try to harness the big brother disposition of Nigeria towards African countries to the economic benefits of both the government and Nigerian international businessmen. Also, the government has made 


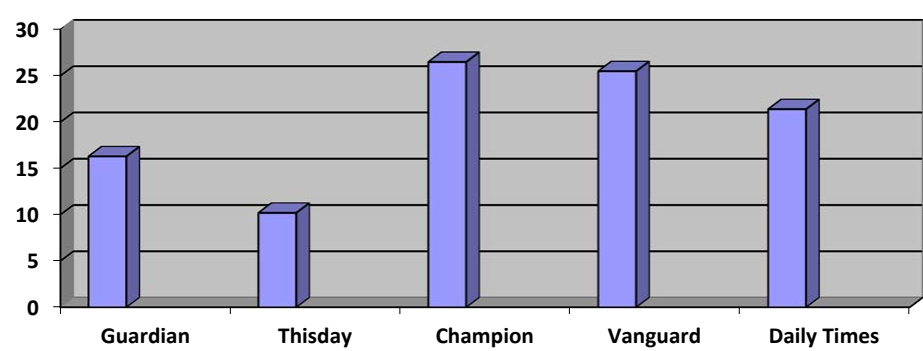

Figure 5: Representation on directionality and prominence on Nigeria's relationship with other African countries.

\begin{tabular}{|c|c|c|c|c|c|c|c|}
\hline Paper Titles & $\begin{array}{c}\text { Favourable } \\
\text { Stories }\end{array}$ & $\begin{array}{l}\text { Unfavourable } \\
\text { stories }\end{array}$ & Neutral & Front Page & Back Page & Inside Page & Total \\
\hline The Guardian & $6(21.4 \%)$ & $1(11.1 \%)$ & $1(9.1 \%)$ & $1(20 \%)$ & $1(50 \%)$ & $6(14.0 \%)$ & $16(16.3 \%)$ \\
\hline This Day & $2(7.1 \%)$ & $2(22.2 \%)$ & $1(9.1 \%)$ & & & $5(11.6 \%)$ & $10(10.2 \%)$ \\
\hline The Champion & $8(28.6 \%)$ & $2(22.2 \%)$ & $4(36.4 \%)$ & & & $12(27.9 \%)$ & $26(26.5 \%)$ \\
\hline The Vanguard & $6(21.4 \%)$ & $2(22.2 \%)$ & $4(36.4 \%)$ & & $1(50 \%)$ & $12(27.9 \%)$ & $25(25.5 \%)$ \\
\hline Daily Times & $6(21.4 \%)$ & $2(22.2 \%)$ & $1(9.1 \%)$ & $4(80 \%)$ & & $8(18.6 \%)$ & $21(21.4 \%)$ \\
\hline Total & $28(100 \%)$ & $9(100 \%)$ & $11(100 \%)$ & $5(100 \%)$ & $2(100 \%)$ & $43(100 \%)$ & $98(100 \%)$ \\
\hline
\end{tabular}

Table 5: Directionality and prominence on Nigeria's relationship with other African countries.

efforts to demand and insist on decent and fair treatment of Nigerian citizens in most African countries, where they may be residing. In recent times, Nigeria has added a new dimension to her foreign policy, what she calls "reciprocity" or "retaliatory" diplomacy as witnessed during Nigerian - South Africa Vaccine card.

\section{Press and Nigeria's foreign policy reportage}

Therefore, within the period of 1999 to 2009, the Nigerian press did not report on a lot of foreign policy issues bordering on Nigeria's relationship with other African countries. However, samples of such stories show that The Daily Champion [17] edition wrote in a headline, FG launches ECOWAS Inter-State Road Transit, the paper noted that the Federal Government launched the ECOWAS Inter-State Road Transit Scheme to facilitate the attainment of free trade within the West African sub-region. In a related story, Vanguard (April 25, 2000) Wrote in a headline entitled: ECOWAS Liberalisation scheme: Nigeria, Ghana meet to Fine Tune Policy. The paper wrote that Nigeria and Ghana are to meet in Accra, Ghana to review the operational modalities of ECOWAS trade liberalisation scheme aimed at free movement of goods and persons in the sub-region. The Guardian, reporting on the trade co-operation between Nigeria and Ghana notes, Nigeria and Ghana may soon float a Joint Shipping Company. Transport Officials from the two countries met last month to work out the modalities for the establishment of the all-important shipping line. Vanguard in another story entitled: ECOWAS trade liberalization commences $20^{\text {th }}$ April goods to enjoy free duty, reported that much awaited ECOWAS Trade Liberalization Scheme (TLS) aimed at guaranteeing free movement of persons and goods in the sub-region. The above stories border on trade relations between Nigeria and some African countries. All these stories are positive to the promotion of good relationships among African nations. However, the problem is that Nigerian press does follow some of these policies to see whether they were implemented. Also, the press does not write extensively through features and editorials on the benefits of otherwise of these policies.

Furthermore, Daily Champion [18], in a story entitled: Nigeria Habours 7,489 refugees, reported that Nigeria is currently accommodating, 7,489, refugees from the more than ig11 African countries. Of the number Cameroon had 1,309 emigrants to the country, Liberia is topping the list with 2,934 refugees. The above story is an approval of Nigeria's big brother disposition to other African countries and portrays the country in positive light [19]. In another economic relations story entitled, "Johannesburg Host Nigeria-South Africa Business Forum". The Vanguard reported that Inter-Africa consulting had concluded plans to organize a yearly business forum to be alternated between South Africa and Nigeria in support of the continued efforts of both governments to explore ways of effectively relating for mutual economic benefit other favourable story headlines include: Envoys calls on Nigerian businessmen to invest in South Africa; "Nigeria, Cameroun meet over Highway" Nigeria, Zambia Relation improving says Envoys" [20]; "Nigerian famers sign pact with Niger Republic counterparts" and "Nigeria, South Africa in strategic partnership". These stories are in line with Nigeria's disposition of becoming the economic hub of Africa.

However, there were some reports considered to be unfavourable in the bid to maintain good relationship between African countries and Nigeria. For instance, a story in the Daily Times entitled: "Nigeria Drug Couriers Deported to Ghana", the paper reported that three Nigerians who were found with narcotics on arrival in Brazil, were deported to Ghana. This is because these Nigerians travelled with Ghanaian passports. The above act by some Nigerian criminals was capable of straining Ghanaian-Nigerian relationship. In an editorial entitled: "Repatriation of Nigerians in Libya, Daily Times wrote on Tuesday, October 3, 2000, about 700 Nigerians who were repatriated from Libya in North Africa. These Nigerians were on the last leg of their attempt to enter Europe through the Mediterranean Sea [21]. Other unfavourable story headlines include "South African Firms Flay Corruption at Nigeria's Ports", "120 Nigerians Languish in Ghanaian prisons" and Cameroun releases Nigerian officials. The unfavourable stories can affect negatively the relationship existing between Nigeria and other African Countries [22]. However, there were more positive stories from Nigerian press on the country's relationship with other African countries. This is in line with developmental theory of the press which emphasize that the press should play the role of promoters of good governance [23]. 
Citation: Onworgu K (2018) The Press and Nigeria's Afrocentric Foreign Policy: A Content Analysis. J Mass Communicat Journalism 8: 366. doi: 10.4172/2165-7912.1000366

Page 7 of 7

RQ1: What are the types and volume (Unit of Analysis) of reportage by the Nigerian press on the selected Nigeria's foreign policies?

This question was taken care of by the data generated through content analysis of the selected newspapers. The question sought to find out the unit of analysis as used in examining on Nigeria's relations with other African countries. The results show that all the papers examined presented the selected foreign policy issues as news stories [24]. However, other units of analysis used by the papers included, editorials, letter to editor, features and photographs. Photographs had the second highest entries in all the newspapers. Furthermore, on the total volume of reports from the five newspapers on the foreign policy issues. Nigeria's relationship with other African countries attracted some reportage from Nigerian newspapers but not as much as expected considering Nigeria's role in African continent [25].

RQ2: What are the directionality and prominence of the Nigerian press reportage on the Afrocentric Policy of Nigeria?

To answer this question, we will use data generated from content analysis. On summary of data on directionality and prominence of newspaper publication). Nigeria's relationship with other African countries had more favourable stories 28 items. Further summary of the directionality of the story show those favourable stories on the five issues had 28 items neutral stories 11 items and unfavourable 9 items. On the prominence of the publications, the results, showed that front page stories had (51 items) back pages ( 2 items) and inside pages (12 items). We can say that Nigeria's relations with other African countries were not prominently reportage on front or back pages since we had more inside page stories [26].

RQ3: What is the content categories of press reports on Nigeria's relation with other African Countries?

From the study, Table 3 was used to answer this question. Therefore, the content categorization on Nigeria's relations with other African countries are (1) Economic relations existing between Nigeria and other African countries; (2) Political relations existing between the country and other African countries; (3) cultural relations existing between the country other African countries; (4) Social relations existing between Nigeria and other African countries; and (5) The reactions of Nigeria citizen to relations.

The bottom line of these categorization of press angles are the benefits derivable from these forms of relationship for citizens and governments of African countries, including Nigeria and Nigerians [5].

\section{References}

1. Saliu HA (2010) Nigerian Responses to US African project in Osita. Reciprocity in Internal relations.
2. Otubanyo F (1989) Introduction: Phases and Changes in Nigeria's Foreign Policy.

3. Akinterinwa BA (2010) The Diplomacy of consequence within the framework of Nigeria - United Kingdom. Reciprocity in International relations.

4. Hunt GT (2000) The Image of Africa as Reflected by the Elite American Press Global Communication and Research paradigm.

5. Asobie A (2010) Fifty Years of Nigeria's Foraign Policy: AN Overview in Eze Nigeria Institute of International Affairs.

6. Busch A (2007) The development of the debate: Intellectual precursors and selected aspects. Globalization, state of the art and perspective.

7. Zimmermann H (2007) Money and Power: Markets and Governance in International Monetary Policy. Globalization, state of the art and perspective.

8. Cheeseman G (2008) Globalization and Military Force. The Globalization of Political Violence.

9. Eze OC (2010) Interrogating the National Interest in Nigeria's Foreign Policy.

10. Albrow M (1996) The Global Age:State and Society beyond modernity. Cam Uni Press.

11. Gill S (1997) Global Structural Change and Multilateralism. Globalisation Democratization and Multilateralism.

12. Axtmann R (1998) Globalization, Europe and the State: Introductory Reflections Globalization and Europe.

13. Salawu (2003) Paradox of Milieu: Communicating in African Indigenous Language in the Age of globalization in Sarari.2: 22.

14. Makacher N (2007) Towards a New international financial order. 139-151.

15. Derefaka AA (2004) Cultural Identity and Globalization: The Nigerian Experience in Oni.

16. Schraeder PJ (2004) African Politics and Society: A Mosaic in transformation Polit Sci Quart 115: 286-288.

17. Daily Champion (2000) p: 19

18. Daily Champion (2000) p: 14.

19. Agwu FA (2010) Reciprocity and its implications international relations. Rec Int Rel.

20. The Guardian (2006) p: 24.

21. The Guardian Thurs (2000) p: 20.

22. Akindele RA (2002) Capacity - Building for the conduct of Niegria's Economic Diplomacy.

23. Akinfeleye. R (1985) "Religious publications pioneers of Nigeria Journalism"

24. Chalkley A (1968) A manual of development journalism. Manila: Thomson Foundation and Press Foundation of Asia.

25. Eze OC (2010) Globalization and the dynamics of external interest in Africa. Recipro Int relat.

26. Fafowora OO (1998) Management Imperarives of Globalization Management in Nigeria. J Nig Ins Manag 34: 2-4. 